著旭至の疏に第性や等ての六

作に続後谷は吾が仁筆比思五本

印がは蔵の研響蒠巻見岳者較想五稿

度現存楞七研鈔首第らな防と考関とは、問

佛し䇴巻にが笅号る山で察し山明題

教、経にあ経ここ外にを、外末

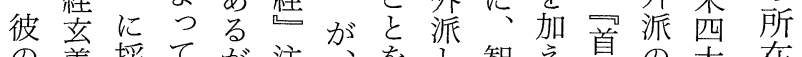

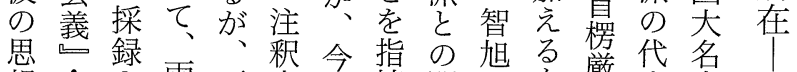

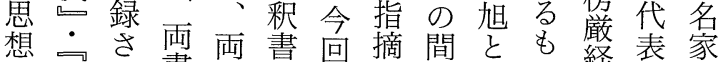

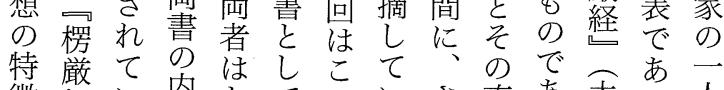

徵経い内容とてのいさ直市㺼る人

老文る容も目研るま前る。藏孤で

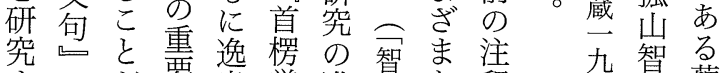

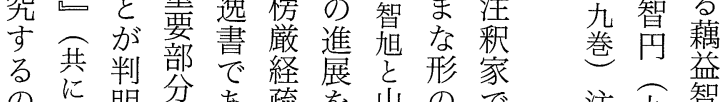

のに明分あ疏を山ので注九橆

に続しはる報曻連あ彩七题

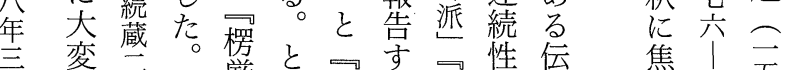

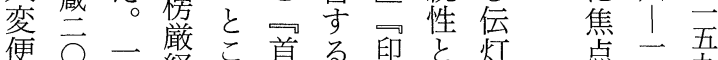

利巻方経集楞。仏韭灼点 ○艻

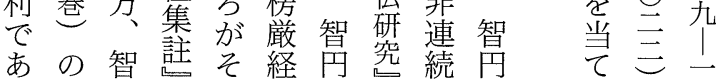

智

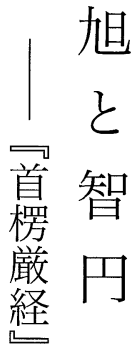

注

釈

の

比

較

に

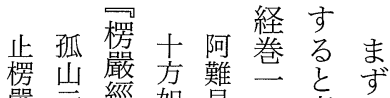

嚴云經㛝見一考初

定得集來佛 $\mathrm{I}$ 号め引

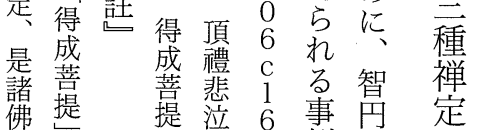

佛提提泣 6 事吕定

路者㗂恨 11 学察を

諢證类舞8 誉尊

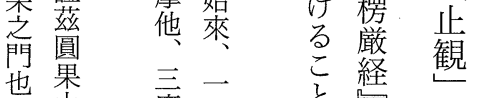

尌思弯潮具る。

る。変実り皦こ

遷質智坚で

に的智注今

る数が釈 畫

樭多智畫智岩

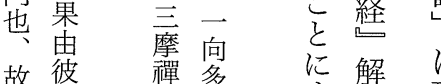

日圓那聞番解配

妙因

最未

九䒩圓初全

他者便䆃

摩 即

禪 一

那 心

殷
繁
譲

全当

般る

的傾

焦

点

を

入初学智

にて 交秎 の 城

浮いす特両

きる彫と山徵者

りい外をが

にう派提と英

す類天示も

る似台点比著

と思俥し 規

を|向 を、想すを

目時家るい

的代のこる 
空たの 引う示引

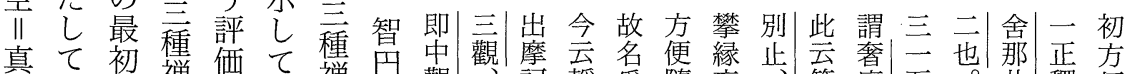

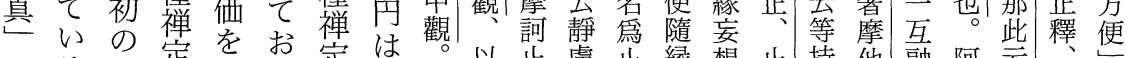

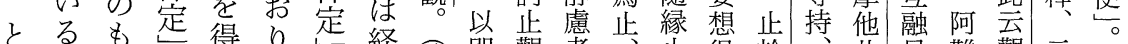
いと㖈のをて う考でを、後を齐略照即靜云者莭道即䣓䕝專三通萊

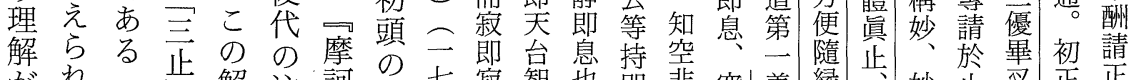

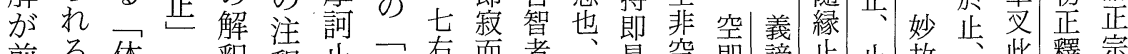

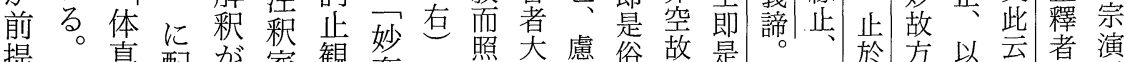

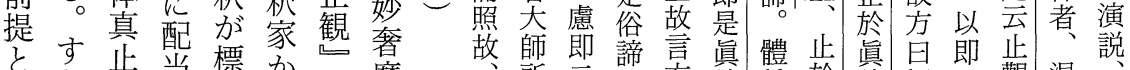

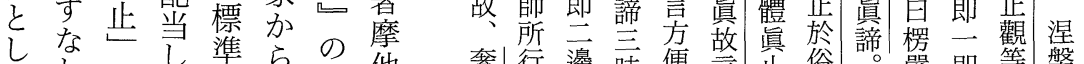

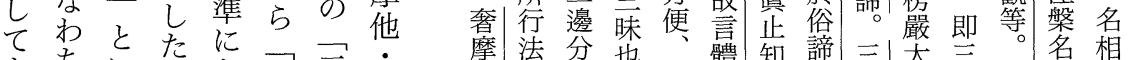

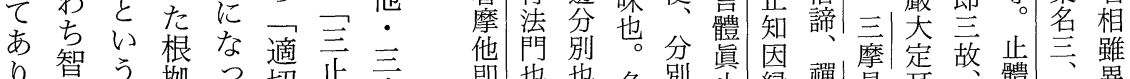

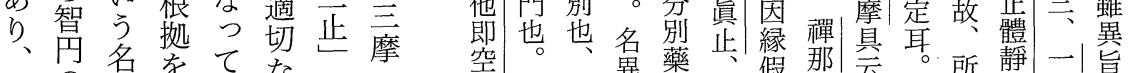

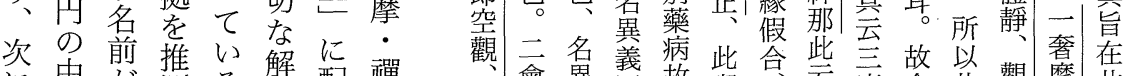
に中が測る解配禪娜會異同故藇会摩今此觀摩在 述で重悉。整当那亲通義。言奢幻瑶提於止體他些

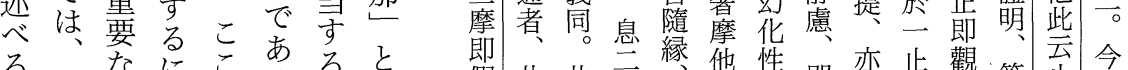

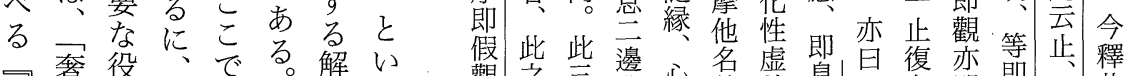

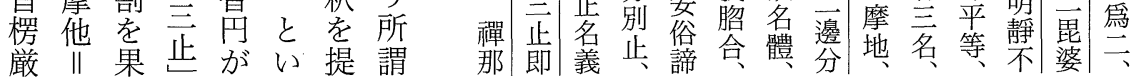

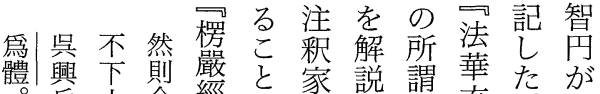

踓十苫經に家説謂華たが述

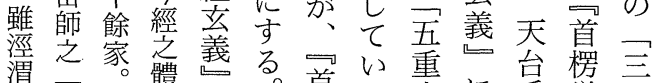
渭涚。體上る。首る玄に䇣撖種 分説於於层楞。義説注経禅

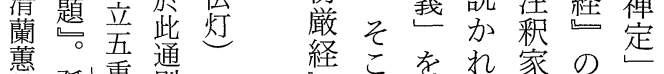
萬。五通 競 孤重别 秀山玄兩 然則義楹 然众之必 於常所何 中住及所

開盲見歸

得 鹞真 正體唯克 亦点山台 或興圓 教 不 則師 而 無貼之解 容空乞釋 議 至經 此 中藏蔬著
ので用るは経を の、い一経体を経 経こて、釈典を止維 体 の、名の党 を項そ! 注常 如自机弁秎住に 何でぞ体を貟配 には考は: 行心当 え智経宗場とる て 典 ‘合 し 注 いやの論、て橎 た智深拥まい想

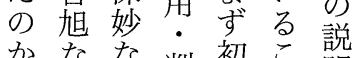
かな判初こ説 自の教教にをで

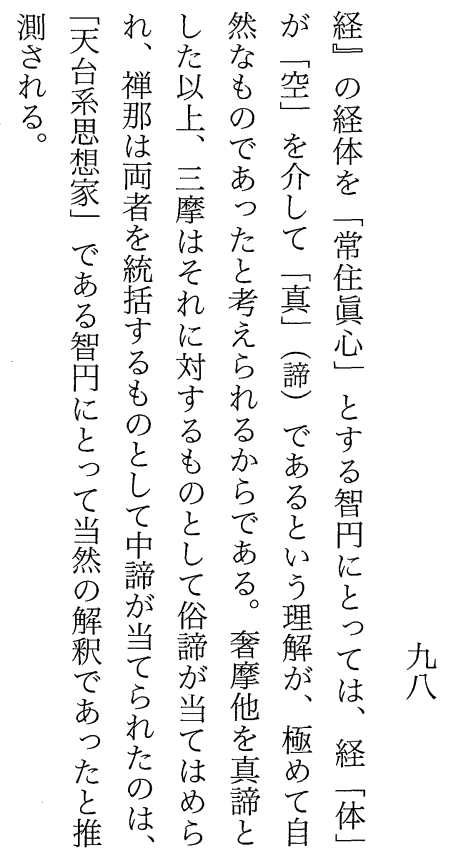




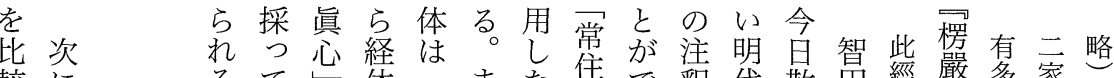

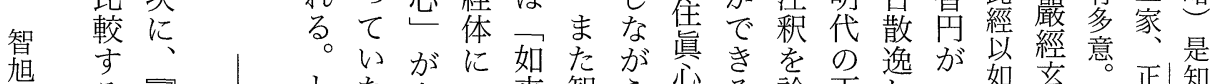

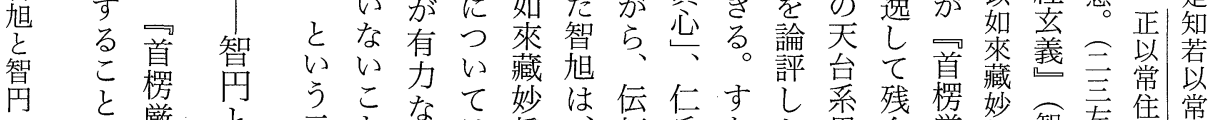

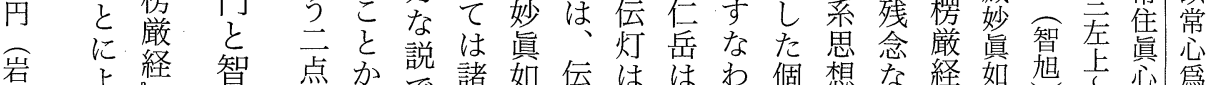

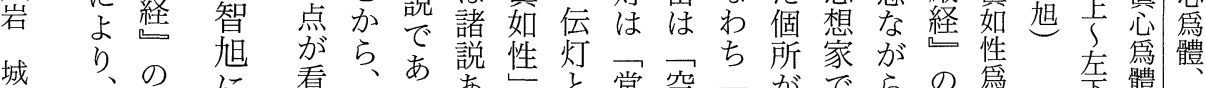

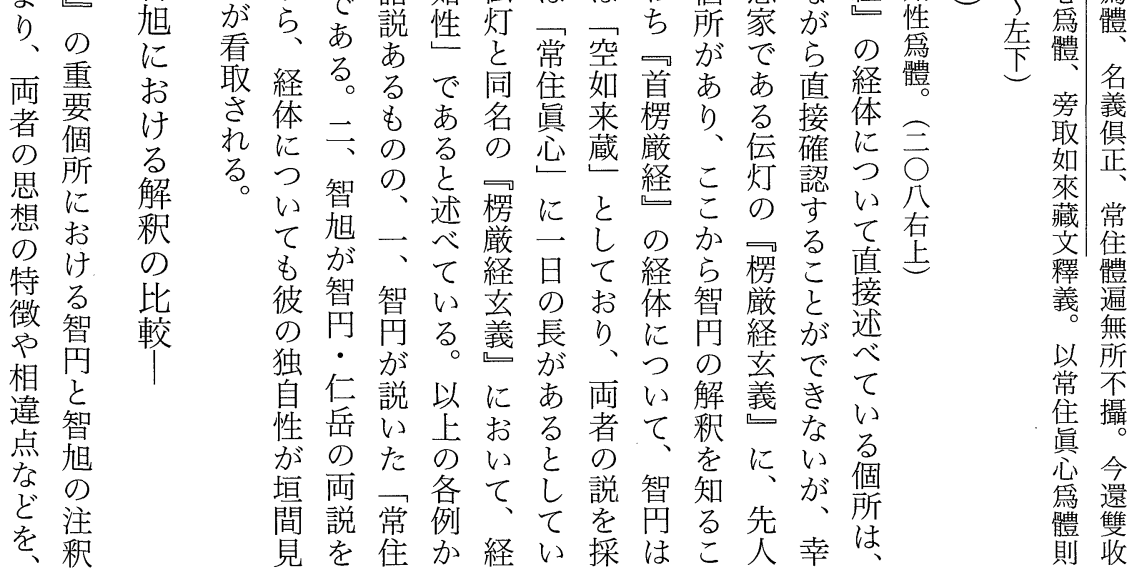

而曰華不所以外正者局將楞由皆二九孤楞輪皆佛経具

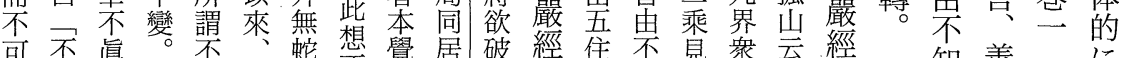

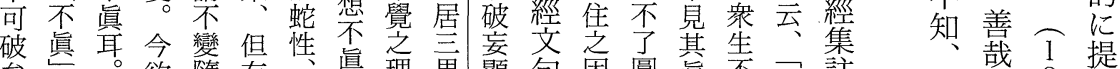

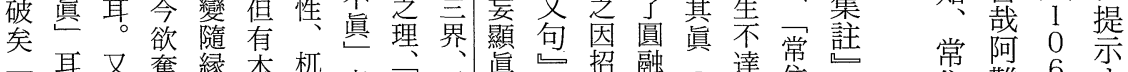

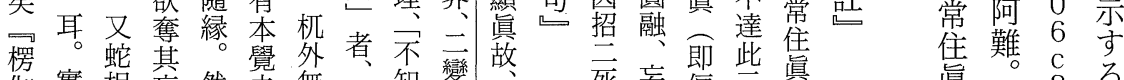

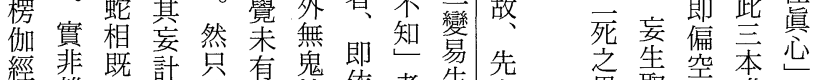

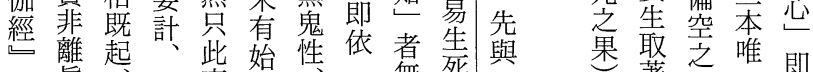
云員故妄覺性常無死與著理

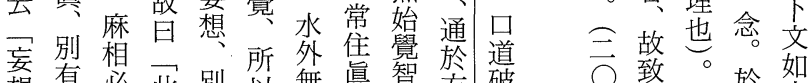
香㤫必此別以無㫐智方破宁致。於如 無㜀隱想無資波心也便也。右輪菩是來 性想息想努性性。實。輪薩是藏

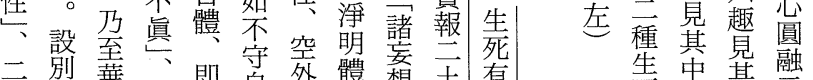

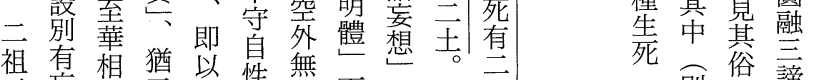
云妄既云炎性橆而者常種气別俗

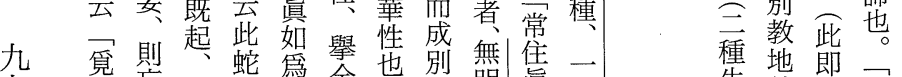

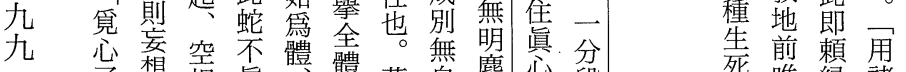

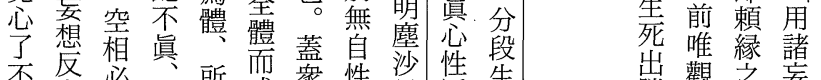

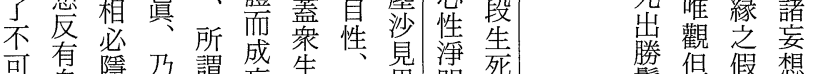

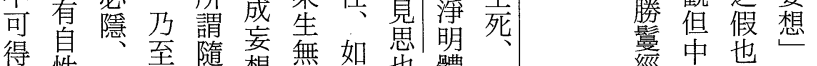

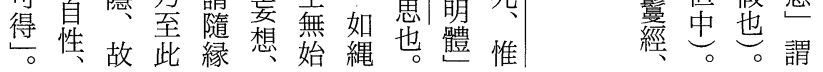

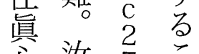
心 婆 7 ?

性賞 2 K

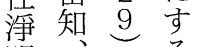
明, る 體 切 用 衆 諸生

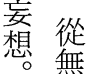
貲聚 覔告 㢣䅡 
此 迷 用妄|故 住有依 眞|切|又住方|眞|由淨縁|明 又 常妙|過|住|此

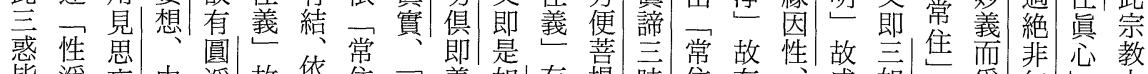

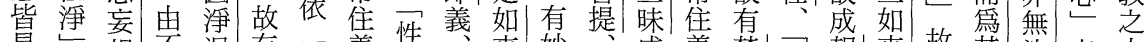

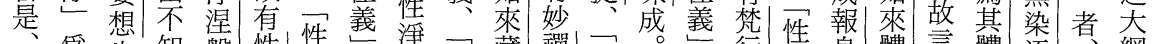

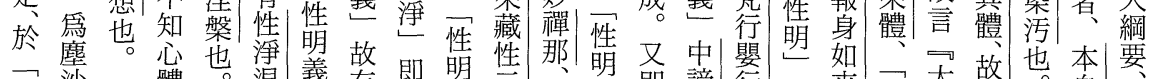

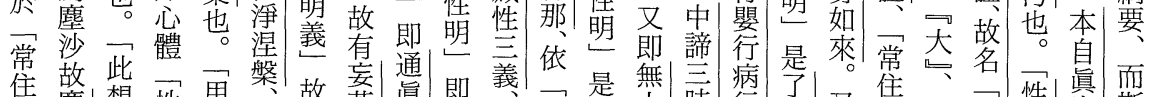

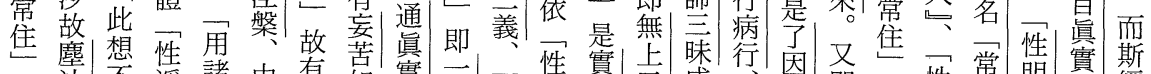

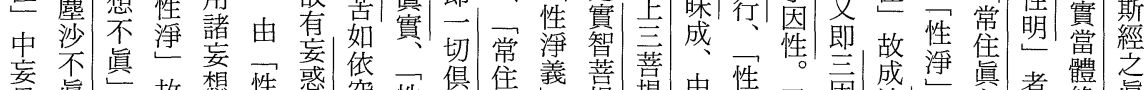

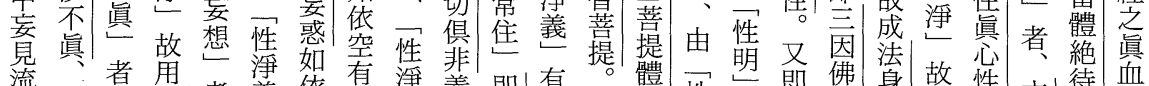

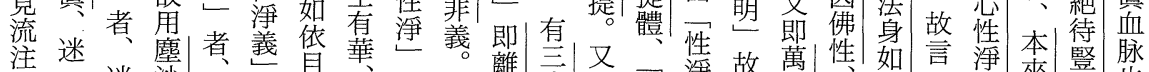

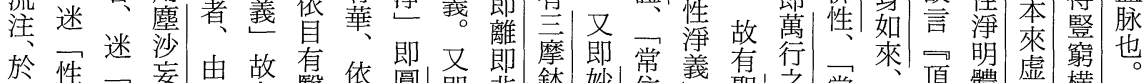

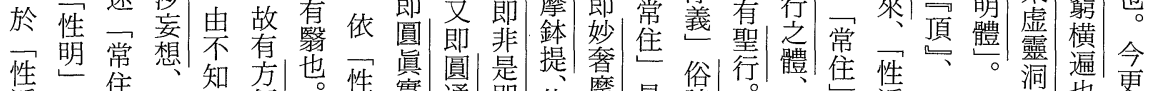

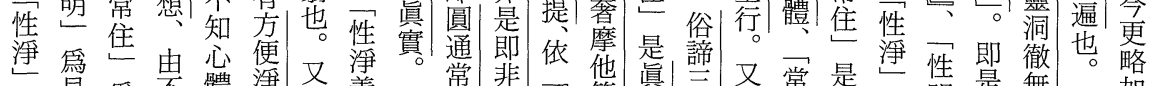

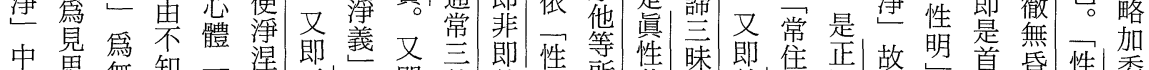

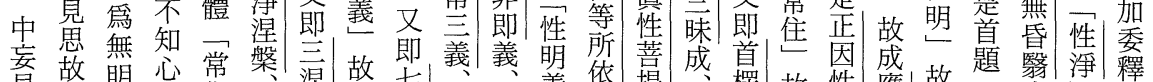

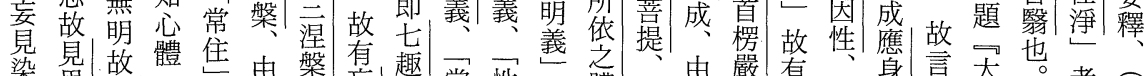

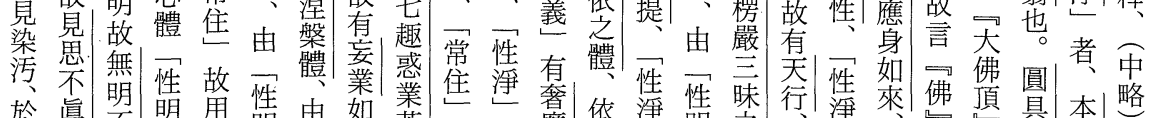

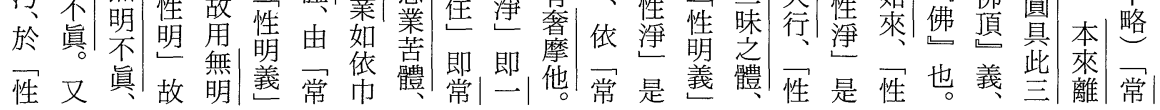

楞性能至妄阿経窺こ特のを仮乘であ

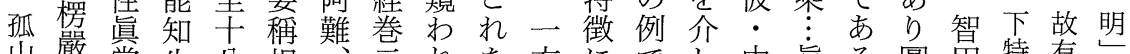

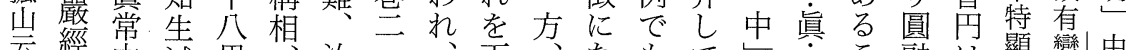

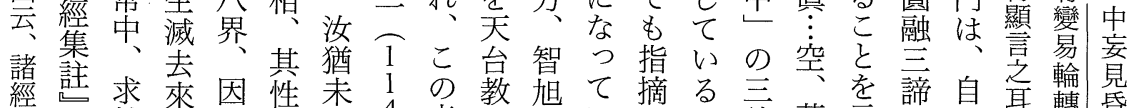

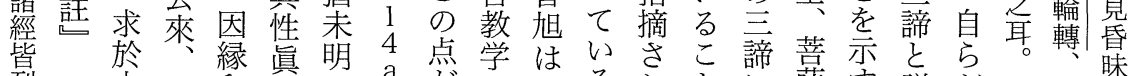

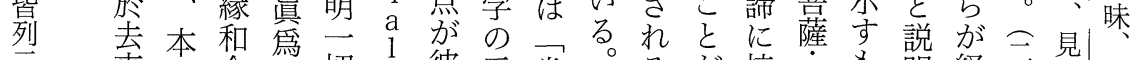

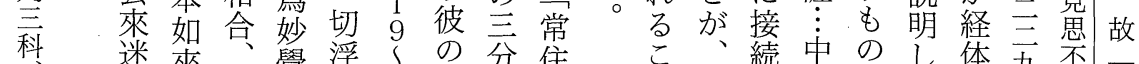

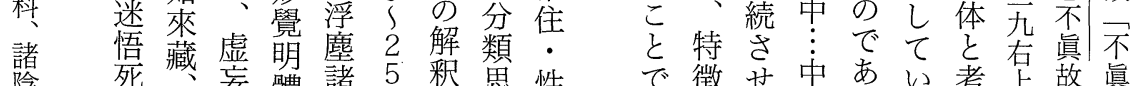

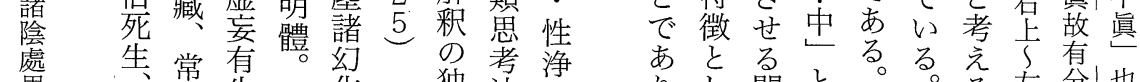

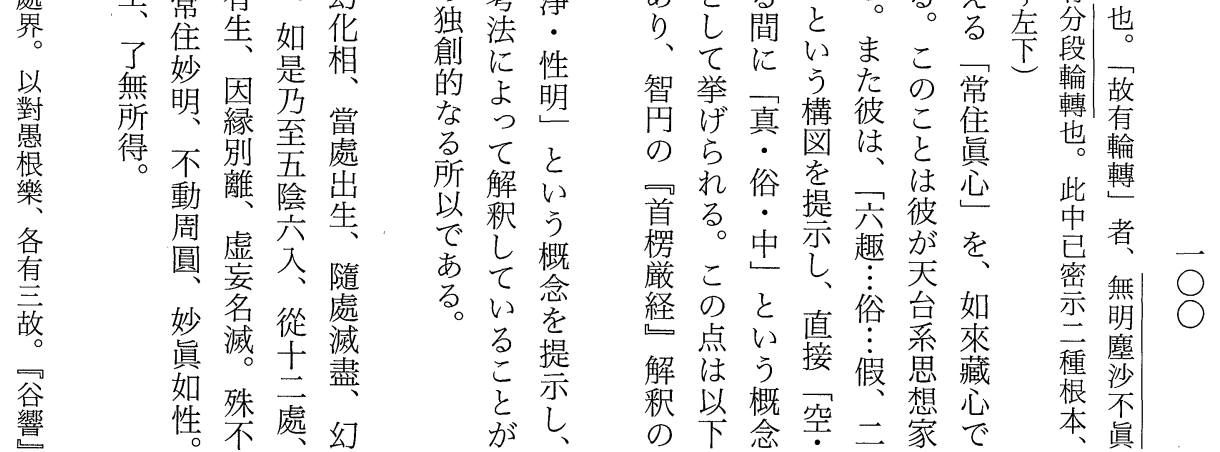


即|無 此楞 故未故|藏|捨 則 凡又而即|往 釋 動 性|三|非|滅 是云

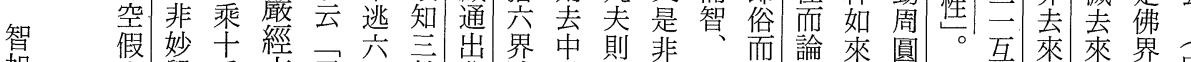

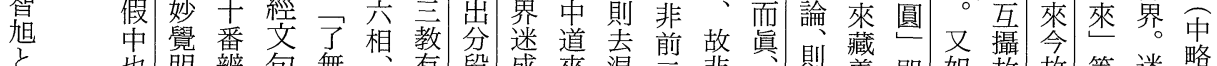

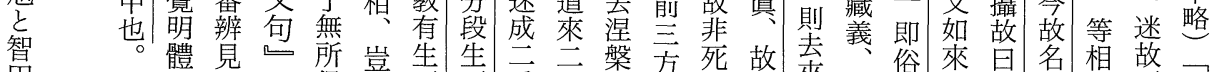

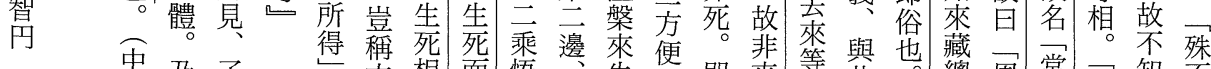

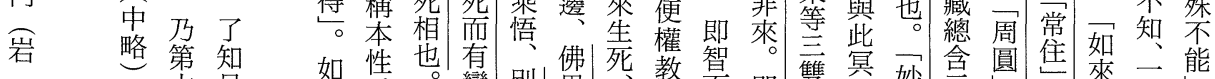

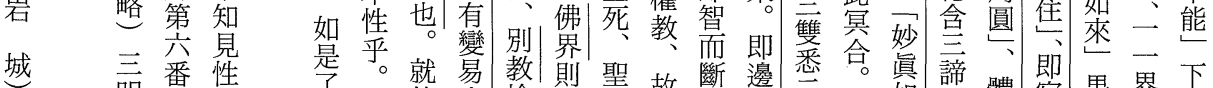

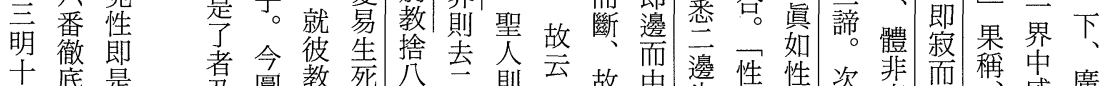

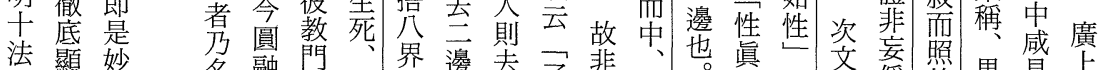

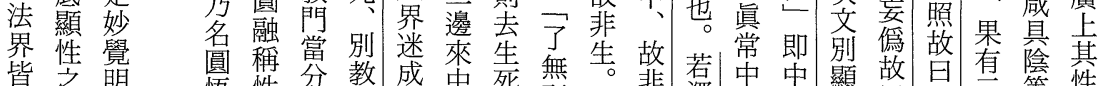

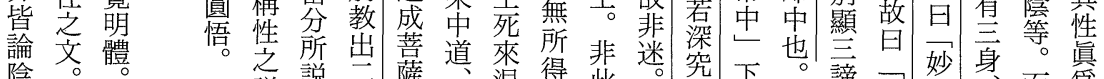

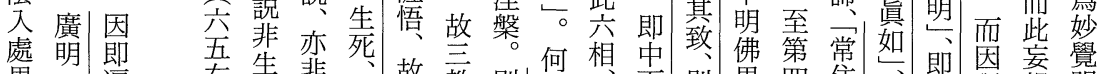

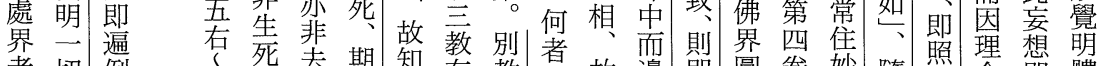

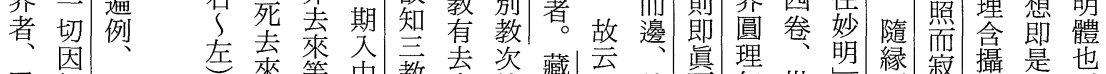

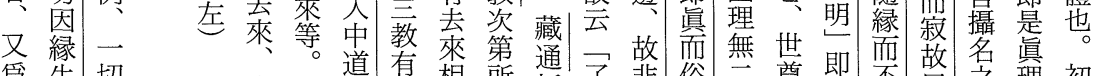

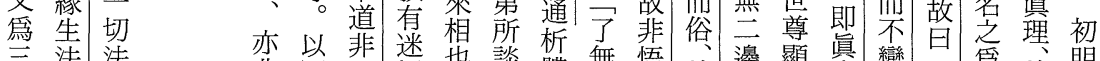

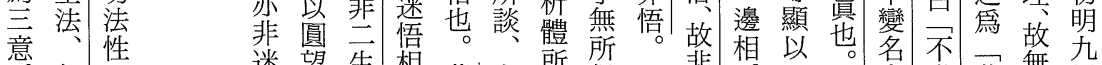

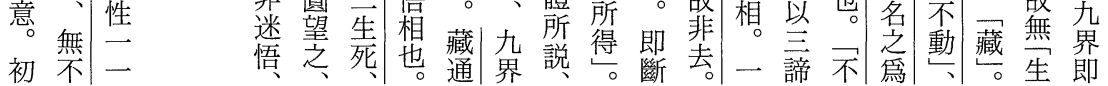

尼 妙 即|羅 即|爲糜 微 藏 界 假 無眞皆八知 至 法淨 佛乃解 法 總 者色中尼中大亦塵性一即所如買界見漏眼不意至脱性示 密故者故陀復色、一中至性實等乃無法淨根佛、非其 如圓名、名羅如、從皆。者。至漏苗色䈆法一漏名 眼具恖如佛尼是皆來是地衆其。四慧意。大|佛切非 識足善色眼者即無大獄苦性十惡眼識乃樂圓眼智 無二

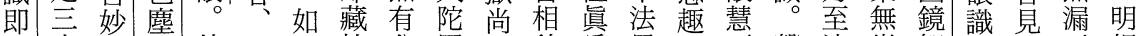
空士色即故如一性分羅即貌临界法耳聲法樂智哦罢五相 假噟。空日眼色全劑尼三歴妙陰界、聞意受平乃佛陰皆

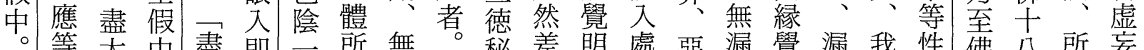
大中。默即切所無。秘差琞處惡漏覺漏我性佛八所妄 即如地。大空切成有县藏別體界有十堺舞舞智身界謂二

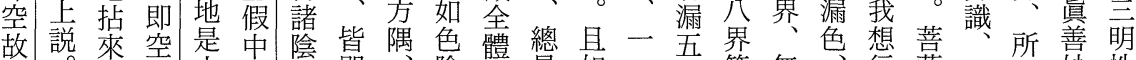

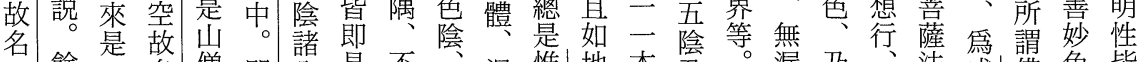

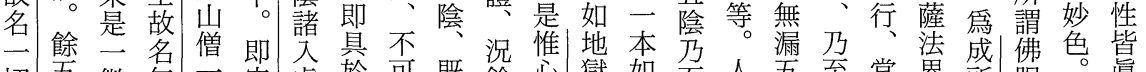
切五微無一空處於可既餘心獄如至人五至常界所眼。県

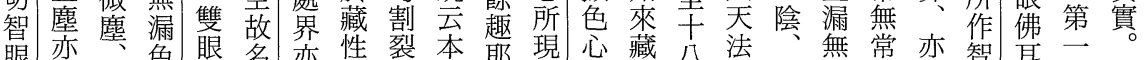

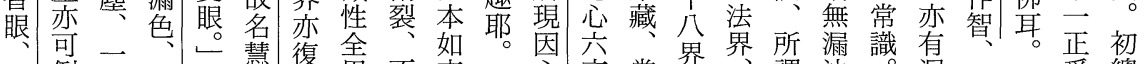

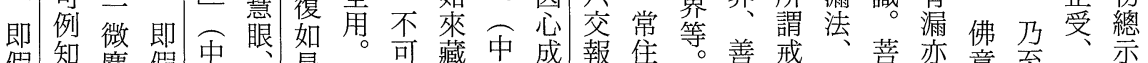

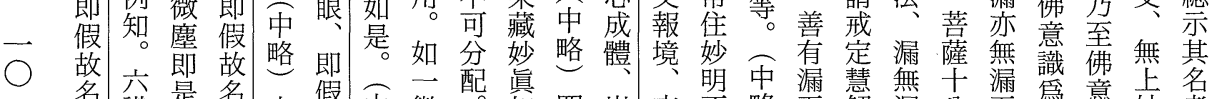

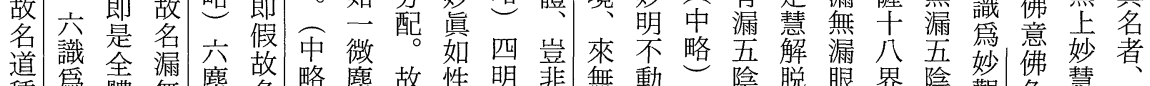

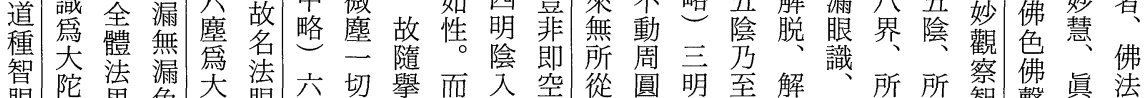

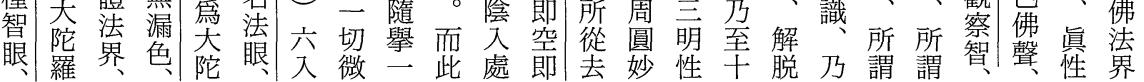
入微一此處即去妙性十脱乃謂謂智蹈性界 
$\tau$ 思真いし

は想心てて天 的、唯台 天必性る心系 台然浄。論思 教で明こを想 学あ体の展家 がっに立開で 説たと場し岁 様飞: 号自派 なし真彼らに 概て忍彼の思属 念首をて想る を楞根臭の智 積簑禁楞最替 極経に箃高は に全い経原 用全体ての淁心 い考経具 る解完体真説 こ积たを灾 なにこ舟なを くい住置張
る学 恶概一ぞ用

智念一心智修欲知切皆即 ら方奆て怒敷見皆哥中 わな明智教明他界容即知名题

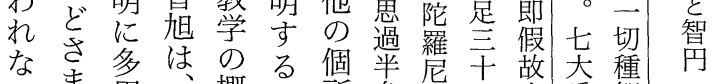

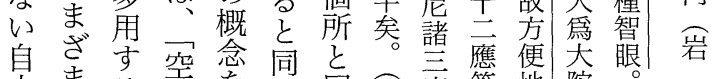

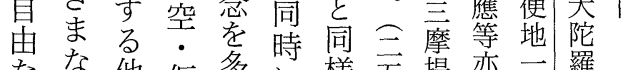
なな解概に仮多に㮞吾提亦切羅見城

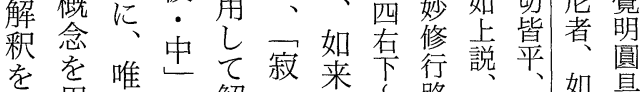
行用識の解照蔵壬路餘即地悬

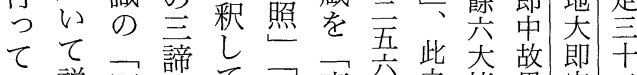
い説四謗て四真公之皆果鱀 る明智いい教立謂苛報霞應

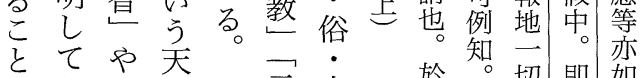
が打口台云中於切即如

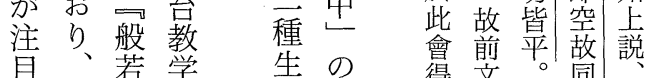
に天否学等 年得交妙居餘 値台教の来帛諦則蔣華地五

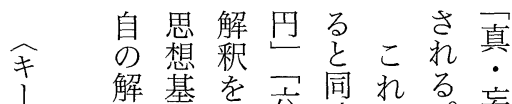

り 解基を监施即時にる。妄

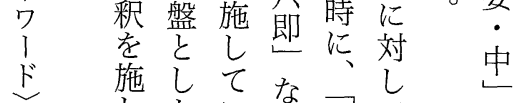

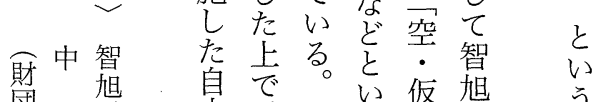

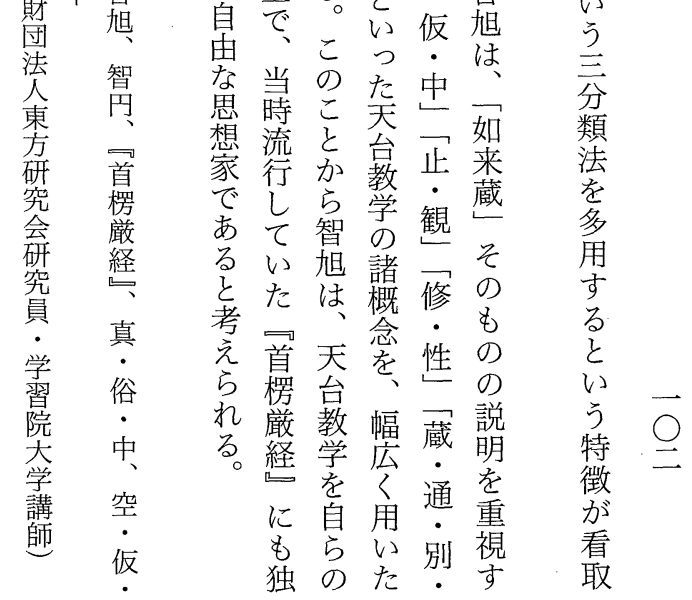




\section{The Teachings of Pure Land and Upholding the Eight Prohibitory Pre- cepts}

Myosei TATSUGUCHI

Previously I have investigated the relationship between faith in Amida Buddha and the precepts, especially the connection to the Eight Prohibitory Precepts as they are portrayed in the Da Amituo jing (『大阿弥陀経』), the Wuliangshou jing (『無量寿経』) and the Guan Wuliangshou jing (『镍無量寿 経』). Upholding the precepts is discussed in five extant Chinese translations of the Larger Sutra of Immeasurable Life (無量寿経): the Da Amituo jing (『 大阿弥陀経』), the Wuliang qingjing pingdengjue jing (『無量清浄平等覚経』), the Wuliangshou jing (『無量寿経』), the Wuliangshou rulai hui (『無量寿如来 会』), and the Dacheng wuliangshou zhuangyan jing (『大乗無量寿荘厳経』). The topic I wish to consider in this article is whether these precepts are a primary factor for awakening or for birth in the Pure Land, and how they came to have this status. Along with the development, spread and establishment of the teachings of Pure Land, the practice of reciting the name of the Buddha was emphasized, to the detriment of other practices. As faith in Amida spread, however, for the sake of good relations with other faiths and institutions, the question of upholding the precepts could not be ignored. From this point of view, upholding the precepts, especially the Eight Prohibitory Precepts, are important to the transmission of the teaching of Pure Land Buddhism.

\section{Zhixu and Zhiyuan's Commentaries on the Shoulengyan jing}

Eiki IWAKI

The purpose of this article is to clarify the thought of Zhiyuan of the Song dynasty and Zhixu of the Ming dynasty, by comparing their commentaries on the Shoulengyan jing. Zhiyuan regards zhenxin (真心) as of greatest import from his weixin (唯心) principle, and often uses the concepts of zhen (真), wang (妄), zhong (中) in his commentary. Zhixu often uses kong (空), jia 
(仮), zhong (中), zhi (止), guan (観), xiu (修), xing (性), cang (蔵), tong (通), bie (別), yuan (円), and other Tiantai doctrines in his commentary.

\section{One Conception of Sattva in Zhiyis Doctrine}

Hōdō SHIOIRI

At the beginning of Chapter Seven of the Vimalakirti-nirdeśa translated by Kumārajīva, thirty comparisons were pointed out to explain thoroughly that sattva is non-existence, namely that it is sünya. These comparisons are classified into three kinds: (1) Existing as phenomena but not existing as real bodies, (2) Not existing theoretically and (3) Not existing in reality in general theories.

Seeing such a classification, Zhiyi regarded these comparisons to understand respectively: (1) Earthly truth for sattva (仮), (2) Essential existence for sattva (空) and (3) Existence enhanced from both existences (中). Particularly, he discussed comparisons of type (3) and elucidated that they existed in fact even though they are impossible at first glance. This explanation is a jump from the context of the sūtra and quite unique from opinions of other scholars.

Though the sutra after this part elucidates the compassion of the bodhisattva, Zhiyi admitting the earthly meaning regards the sattva, the object of the bodhisattva's compassion, as not a complete śünya and thus finds a foundation for compassion.

\section{Zhiyi’s Intention of the Secret Teaching 秘密不定教}

Kōshi CHōDō

When we look closely into the Fahua xuanyi 法華玄義, it is often mentioned that enlightenment can be attained secretly by people with the capacity of the two vehicles.

In the Tiwei boli jing 提謂波利経, which expounds the Five Precepts and the Ten Good Acts 五戒十善 to lay believers in the secular world, it is men- 